\title{
ANALISIS KADAR PROTEIN PADA BAKASANG DARI JEROAN IKAN CAKALANG (Katsuwonus pelamis Lin)
}

\author{
Farida Bahalwan, Dosen Program Studi Pendidikan Biologi, \\ Fakultas Keguruan dan Ilmu Kependidikan, UNIDAR Ambon, \\ 081344872000, E-mail: farida_bahalwan@gmail.com
}

\begin{abstract}
Abstrak: Penelitian ini bertujuan untuk mengetahui mengetahui berapa besar kadar protein yang terkandung pada bakasang dari jeroan ikan cakalang (katsuwonus pelamis, Lin). Jenis penelitian yaitu deskriptif kualitatif, yaitu mengetahui kadar protein pada bakasang dari jeroan ikan cakalang (Katsuwonus pelamis Lin). Hasil penelitian menunjukan kadar protein pada bakasang dari jeroan ikan cakalang (Katsuwonus pelamis Lin) pada ulangan pertama sebesar 4,20 \%, ulangan kedua sebesar 4,35 \%, dan ulangan ketiga 4,50 \% dan hasil hitung rata - ratanya adalah 4,35\%. Berdasarkan hasil tersebut membuktikan bahwa masih terdapat protein pada bakasang dari jeroan ikan cakalang yang sudah mengalami proses pengolahan secara tradisional.
\end{abstract}

\section{Kata Kunci: Ikan Cakalang, Bakasang, Protein}

\section{ANALYSIS of the LEVELS of PROTEIN in the BAKASANG of OFFAL FISH SKIPJACK TUNA (Katsuwonus pelamis, Lin)}

\begin{abstract}
This research aims to know know how much protein is contained in bakasang of the offal fish skipjack tuna (Katsuwonus pelamis, Lin). This type of research is qualitative descriptive is knowing the levels of protein in the bakasang of offal fish skipjack tuna (Katsuwonus pelamis, Lin). Results of the study showed the levels of protein in the bakasang of offal fish skipjack tuna (Katsuwonus pelamis, Lin) in deuteronomy first is $4,20 \%$, for the second test is $4.35 \%$, third repeat of $4.50 \%$ and average is $4.35 \%$. Based on those results prove that there is still a protein on bakasang of offal tuna are already experiencing the traditional processing process
\end{abstract}

Keyword: Skipjack Tuna, Bakasang, Protein 
Ikan merupakan salah satu sumber protein hewani dan juga memiliki kandungan gizi yang tinggi diantaranya mengandung mineral, vitamin, dan lemak tak jenuh. Protein sangat dibutuhkan tubuh untuk proses pertumbuhan dan mengganti sel-sel tubuh yang telah rusak. Selain air, protein merupakan bagian utama dari unsur - unsur penyusun tubuh manusia.Salah satu makanan yang mengandung protein tinggi adalah ikan yaitu sekitar $20 \%$, disamping itu protein yang terkandung dalam ikan mempunyai mutu yang baik, sebab sedikit mengandung kolesterol dan lemak.

Propinsi Maluku merupakan salah satu wilayah kepulauan di Indonesia yang banyak menghasilkan hasil laut dan darat. Salah satu hasil laut yang banyak di hasilkan oleh nelayan maluku yaitu ikan diantaranya ikan cakalang (Katsuwonus pelamis). Seperti yang kita ketahui ikan merupakan bahan pangan yang mudah rusak (membusuk), hanya dalam waktu sekitar 8 jam sejak ikan ditangkap dan di daratan sudah akan timbul proses perubahan yang mengarah kepada kerusakan, Karena itu agar ikan dan hasil perikanan lainnya dapat dimanfaatkan semaksimal mungkin, perlu dijaga kondisinya. Pengolahan merupakan salah satu cara untuk mempertahankan ikan dari proses pembusukan.

Pengolahan secara tradisional yang sudah umum di kenal adalah ikan asin, ikan asap, dan produk fermentasi seperti ikan kecap, terasi dan bakasang. Pada umumnya proses pengolahan ikan cakalang seperti pengasapan dan penggaraman hanya memanfaatkan bagian dagingnya saja, sedangkan bagian lainnya seperti jeroan (usus, lambung, hati, jantung, paru-paru dan telur) umumnya dibuang dan sebagian dimanfaatkan sebagai produk sampingan. Sifat ikan yang cepat mengalami pembusukan mengakibatkan ikan tidak dapat dikonsumsi dalam keadaan segar di tempat yang jauh dari tempat asal sedangkanproduksi tidak selamanya stabil karena dalam sekali penangkapan jumlahnya bervariasi. Pada musim panen produksi melimpah dan harganya murah, usaha pengawetan sangatlah diperlukan. Dalam proses pengawetan dan pengolahan ikan, pada umumnya jeroan ikan dibuang. Padahal sebagian besar limbah tersebut merupakan sumber lemak, protein,dan vitamin. Menurut Subroto,dari seekor ikan cakalang segar dengan berat kira-kira $2 \mathrm{~kg}$, limbahnya mempunyai presentasi sebesar 5-75\% atau sebesar kira-kira 95 sampai 110 gram, jumlah yang besar ini merupakan limbah hasil perikanan yang perlu dimanfaatkan agar tidak terbuang.

Penanganan, penyimpanan, dan pengawetan bahan pangan sering terjadi perubahan nilai gizinya, yang sebagian besar tidak diinginkan. Zat gizi yang terkandung dalam bahan akan rusak pada sebagian besar proses pengolahan karena sensitif terhadap $\mathrm{pH}$, oksigen, sinar, dan panas. Salah satu dari produk ikan cakalang yang sangat digemari masyarakat Maluku yaitu bakasang. Bakasang merupakan olahan jeroan ikan cakalang 
yang dalam proses pengolahannya dilakukan penambahan garam dengan tehnik fermentasi dan penyimpanan dalam botol diletakan disamping tungku masak yang memungkinkan adanya pemanasan dan berakibat turunnya nilai gizi sebab dengan pemanasan tersebut, dimana protein akan mengalami denaturasi artinya struktur proteinya akan berubah.

\section{METODE PENELITIAN}

Tipe penelitian yang digunakan dalam penelitian ini adalah deskriptif kualitatif, yaitu mengetahui kadar protein pada bakasang dari jeroan ikan cakalang (Katsuwonus pelamis. Lin).

Yang menjadi objek dalam penelitian ini adalah kadar protein bakasang dari jeroan ikan cakalang yang diambil sebanyak 5 gram untuk tiap kali perlakuan.

Variabel yang digunakan dalam penelitian ini adalah variabel tunggal yaitu kadar protein pada bakasang dari jeroan ikan cakalang (Katsuwonus pelamis).

1. Data Primer, yaitu data yang diperoleh langsung pada saat mengadakan penelitian.

2. Data Sekunder, yaitu data yang dikumpulkan melalui literatur, referensi atau informasi ilmiah yang berkaitan dengan permasalahan yang diteliti.

\section{Pembuatan Bakasang}

1. Ikan cakalang diambil isi perutnya atau jeroannya (usus, lambung, hati, jantung, paruparu dan telur) dan langsung dicuci bersih

2. Jeroan yang sudah bersih dicincang halus, sesudah itu diberi garam

3. Kemudian dimasukan di dalam sebuah tempat yang tertutup rapat (Botol)

4. Disimpan dalam keadaan tertutup, dan diletakan disamping tungku masak.

\section{Analisis Protein Pada Bakasang}

1. Pengambilan sampel yaitu bakasang dari jeroan ikan calakang

2. Timbang saksama 0,51 gram cuplikan (sampel). Kemudian di masukan ke dalam labu kjedhal $100 \mathrm{ml}$.

3. Tambah 2 gram campuran selen dan $2.5 \mathrm{ml} \mathrm{H}_{2} \mathrm{SO}_{4}$.

4. Memanaskan labu kjedhal diatas pemanas listrik/ api pembakar sampai mendidih dan larutan menjadi jernih kehijau-hijauan (sekitar 2 jam)

5. Biarkan dingin kemudian encerkan dan masukan ke dalam labu ukur $100 \mathrm{ml}$, tepat sampai tanda garis.

6. Pipet $5 \mathrm{ml}$ larutan dan masukan ke dalam alat penyuling, tambahkan $5 \mathrm{NaOH} 30 \%$ dalam beberapa tetes indikator pp. 
7. Sulingkan selama kurang lebih 10 menit. Sebagai penampung gunakan $10 \mathrm{ml}$ larutan asam borat $2 \%$ yang telah di campur Indikator.

8. Bilas ujung pendingin dengan air suling

9. Titrasi dengan larutan $\mathrm{HCl} \mathrm{0,01} \mathrm{N.}$

10. Kerjakan penitraan blangko.

Untuk mengetahui ada berapa persentase kadar protein bakasang dari jeroan ikan cakalang (Katsuwonus pelamis) maka di gunakan rumus sebagai berikut:

$\%$ Protein $=\frac{(\mathrm{V} 1-\mathrm{V} 2) \mathrm{N} \times 0,014 \times \mathrm{FK} \times \mathrm{FP} \times 100}{\mathrm{~W}}$

Keterangan : V1 = ML contoh

$\mathrm{V} 2=$ ML blangko

$\mathrm{N}=$ Normalitas

$\mathrm{FK} \quad=$ Faktor konversi

$\mathrm{FP} \quad=$ Faktor pengenceran

$\mathrm{W} \quad=$ Bobot sampel

\section{HASIL DAN PEMBAHASAN}

Penelitian ini dilaksanakan di Laboratorium Balai Riset dan Standarisasi Maluku dan sampel bakasang dari jeroan ikan cakalang dibuat sendiri sesuai dengan prosedur pembuatan bakasang, pembuatan sampel pada hari Kamis tanggal 7-13 November 2012 dan pengujian protein di Laboratrium Balai Riset dan Standarisasi Maluku dilaksanakan pada hari Selasa 13 November 2012 dengan menggunakan metode SNI 01-2891-1992, dan diperoleh hasil uji kadar protein pada bakasang dari jeroan ikan cakalang (Kasuwonus pelamis,Lin) seperti terlihat pada tabel 4.1 di bawah ini:

Tabel 1 Kadar protein bakasang jeroan ikan cakalang (Kasuwonus pelamis,Lin).

\begin{tabular}{|c|c|c|}
\hline No & $\begin{array}{c}\text { Kode Sampel } \\
\text { (Bobot Sampel) }\end{array}$ & Hasil uji kadar protein (\%) \\
\hline 1 & $1(0,5139 \mathrm{~g})$ & $4,20 \%$ \\
\hline 2 & $2(0,5186 \mathrm{~g})$ & $4,35 \%$ \\
\hline 3 & $3(0,5222 \mathrm{~g})$ & $4,50 \%$ \\
\hline \multicolumn{2}{|c|}{ Rata -rata } & $4,35 \%$ \\
\hline
\end{tabular}

Berdasarkan hasil penelitia menunjukan bahwa terdapat kadar protein pada bakasang dari jeroan ikan cakalang (Katsuwonus pelamis, Lin) pada ulangan pertama dengan bobot sampel 0,5139 sebesar 4,20 \%, ulangan kedua dengan bobot sampel 0,5186 
sebesar 4,35 \%, dan ulangan ketiga dengan bobot sampel 0,5222 sebesar 4,50\% dan hasil hitung rata - ratanya nilai proteinnya adalah $4,35 \%$. Kadar protein yang ada pada bakasang dari jeroan ikan cakalang dari hasil penelitian disebabkan jeroan memiliki enzim protein dan asam amino yang cukup tinggi. Menurut Hidayat (1994) adanya kadar protein disebabkan jeroan merupakan sumber enzim proteolitik yang cukup tinggi terutama pada bagian pilorikaeka, lambung, dan usus seperti enzim tripsin, kemotripsin dan pepsin. Protein selain terdapat pada daging ikan, protein juga terdapat pada sirip, kulit, darah, pigmen otot, sel-sel hati, ginjal serta bagian-bagian isi perut dan hampir seluruhnya adalah berisi protein

Protein ikan mengandung asam amino esensial maupun asam amino nonesensial. Protein merupakan suatu zat makanan yang paling penting bagi tubuh karena berfungsi sebagai zat pengatur dan pembangun, selain itu protein juga berfungsi sebagai bahan bakar dalam tubuh. Kadar protein dalam makanan merupakan suatu faktor yang dapat dijadikan bahan pertimbangan tersendiri bagi konsumen. Protein mempunyai beberapa sifat fungsional yang berperan penting dalam pembentukan karakteristik yang diinginkan, mutu makanan dan penerimaan oleh konsumen (seperti penampakan, warna, tekstur dan cita rasa). Pada setiap produk pangan, protein dapat berperan sebagai pengemulsi, pengikat air, pembentuk tekstur, kekentalan, penyerap lemak, dan pembentuk buih.

Jenis-jenis protein umumnya digolongkan menjadi protein globular, protein serat, dan protein konyugasi. Pada penelitian bakasang dari jeroan ikan cakalang termasuk pada jenis Protein globular karena protein globular mempunyai sifat dapat larut dalam larutan garam dan asam encer dan mudah berubah dibawah pengaruh suhu, konsentarsi garam, dan pelarut asam-basa. Protein ini dapat mengalami denaturasi dengan pemanasan yang mengakibatkan susunan molekulnya berubah yang diikuti dengan perubahan sifat fisik. Mutu protein dilihat dari perbandingan asam-asam amino yang terkandung dalam protein pada makanan. Pada prinsipnya suatu protein yang dapat menyediakan asam amino esensial dalam suatu perbandingan yang menyamai kebutuhan manusia, mempunyai mutu yang tinggi, sebaliknya protein yang kekurangan salah satu atau lebih asam amino esensial mempunyai mutu yang rendah. Protein yang berasal dari hewan seperti ikan, telur dan susu dapat menyediakan asam-asam amino esensial dan karenannya disebut protein dengan mutu tinggi. Kalau protein dengan mutu rendah terlalu banyak dikonsumsi dengan menunya tidak beraneka ragam, akan berakibat kurangnya asam amino pembatas dan orang akan menderita gejala-gejala yang tidak dikehendaki sehingga akan menyebabkan timbulnya penyakit kuashiorkor pada bayi dan anak kecil, marasmus dan busung lapar serta menurunya tingkat kecerdasan terutama pada anak-anak. 


\section{KESIMPULAN}

Setelah dilakukan penelitian pada sampel sesui dengan prosedur penelitian kadar protein pada bakasang dari jeroan ikan cakalang (Katsuwonus pelamis Lin) pada ulangan pertama sebesar 4,20 \%, ulangan kedua sebesar 4,35\%, dan ulangan ketiga 4,50\% dan hasil hitung rata - ratanya adalah $4,35 \%$.

\section{SARAN}

1. Agar masyarakat yang ingin membuat bakasang dari jeroan ikan cakalang, sebelum dikonsumsi perlu diolah dengan baik.

2. Agar dinas kesehatan perlu mengadakan pemeriksaan bagi produk-produk olahan masyarakat agar dapat memenuhi kebutuhan protein pada tubuh.

3. Diharapkan mahasiswa dapat mengadakan pengembangan penlitian lanjutan yang berkaitan dengan judul penelitian ini.

\section{DAFTAR PUSTAKA}

Adawyah Rabiatul. 2008. pengolahan dan pengawetan ikan. Bumi Aksara. Jakarta.

Andarwula Nuri, dkk. 2011. Analisis Pangan. PT Dian Rakyak. Jakarta.

Aulia. 2004. Gizi dan Pengelolaan Pangan. Adicita Karya Nusa. Yogyakarta.

Balai Riset Standarisasi Maluku. 2009. Penuntun Cara Uji Makanan dan Minuman. Ambon.

Endang, Supriyatna, Didi dan Arief Faud. 1992. Penuntun Praktikum Kimia Makanan,

Akademik Kimia Analisis. Bogor Pusat Pendidikan dan Pelatihan Pegawai Depertemen Perindustrian Bogor

Lehninger. 1982. Biokimia. Erlangga. Jakarta.

Nuraini Raham. 2008. Tehnik Pengolahn Ikan Untuk Dikonsumsi Dengan Metode Fermentasi Ensiling. Institut Petanian Bandung. Bandung.

Nyoman, 2001. Kamus Kimia. Rineka Cipta. Jakarta. 